\title{
The Emancipatory and Transformative Potentials of American Multiethnic Women Writing
}

\author{
Hussein Hasan Zeidanin \\ Tafila Technical University \\ College of Arts - Department of English \\ P.O. Box 179, Tafila 66110, Jordan \\ E-mail: husseino_z@yahoo.com
}

Received: 18-09-2015

Published: 01-03-2016
Accepted: 08-12-2015

doi:10.7575/aiac.ijalel.v.5n.2p.83
Advance Access Published: December 2015

URL: http://dx.doi.org/10.7575/aiac.ijalel.v.5n.2p.83

\begin{abstract}
This paper explores the emancipatory potentials of American women writers of color for victims of gender, class, and the ethnocentric ideologies of racism, colonialism and nationalism. Their struggle against multiple oppressors, on one hand, drive them to form alliances with different oppressed groups such as laborers, homosexuals, the colonized people, immigrants and various ethnic minorities. On the other hand, cultural and ethnic identities are redefined on the basis of heterogeneity rather than homogeneity to cultivate tolerance, interdependence and mutual respect; gender roles are reconsidered in the light of an androgynous ideology, which views men and women as equal partners who should live in harmony but not in conflict; social classes are deconstructed to redress the injustices women and laborers have endured because of their gender, ethnic or racial differences. The plurality and heterogeneity of cultural, ethnic and gendered identities which women writers of color develop are extended to their writing whose language, content, and style are innovated and used as effective strategies to empower and emancipate subaltern groups. Their writing, therefore, assumes an inclusive character in which sexual, cultural and ethnic boundaries disappear, and interracial, intercultural, interethnic and intersexual dialogue is promoted.
\end{abstract}

Keywords: American women of color, writing, empowerment, potentials, innovative strategies

\section{Introduction}

My paper argues that American multiethnic women's writing reflects upon the socio-cultural and economic standing of American women of color and relates the reformation of their sociopolitical roles and reconstruction of their ethnic identities within a multi-cultural environment to the triggering experiences of alienation and subjugation in nationalist and patriarchal societies. American multiethnic women's writing, I accordingly contend, has the potentials to empower victims of gender, class, race, and ethnocentrism, drastically change the sociocultural landscapes of the American society and develop a more diverse and pluralistic culture that appreciates difference and reinforces coexistence and cooperation among various ethnic groups. I also maintain that it assumes a more hybrid character in its language and content and accentuates the significance of creativity, idiosyncrasy and subjectivity for the subversion of the masters' intellectual hegemony and the empowerment of the oppressed and subordinated. My feminist readings of the works of Anna Castillo's So Far From God, Louis Erdrich's Love Medicine, Maxine H. Kingston's Woman Warrior, Toni Morrison's Beloved and Viramontes' The Moths reveal the writers' firm determination to defy sexist, classist and ethnic oppression, and their repressed desire to bring about socio-cultural changes and redefine ethnocultural and gender identifications. Relevant to the arguments made and questions raised in this paper is the theory of the Third World feminism which arose in response to the hegemonic discourse of the mainstream Anglo-American feminism and sought to address the particular concerns of women in the Third World countries and minority ethnic communities in the United States and elsewhere.

\section{Potentials of Empowerment}

Ogbuehi (1999) explores the concepts of power and empowerment and distinguishes two concepts of power. In one sense, power refers to the exercise of control over others which feminists consider the major source of conflict between the two genders. In another sense, power is conceived as the capacity to achieve goals and change by relying more on creativity than on violence. The word 'empowerment' is derived from 'empower' and means to provide someone with the power or the right to do something. The concept of power writers usually appropriate into their works, Ogbuehi emphasizes, either heightens violence like in the works of misogynists and sexists or enhances gender equality and interdependence like in the works of androgynists such as Virginia Wolf. Accordingly, women's empowerment is perceived not as "the search for power to control others by the use of force but power generated from peaceful sources." (44) Female writers should, therefore, discard the gendered hierarchical discourse male writers engender in their works and opt to a more tolerant gender discourse in struggling for their liberties and rights. 
Ogbuehi further views literature as a source of empowerment in her assumption that "literature, that great mirror of society, is a source of empowerment for women.... It provides them the avenue for self-expression. Women have fought their wars with their pens and have changed social attitudes and entrenched anachronistic views about women through writing." (45) Literature in this sense has the potentials to break the walls of silence characterizing women's age-long indifference about their physical oppression, sexual exploitation and social subordination. It has the potentials to freely voice women's concerns and aspirations, and to change the stereotypical images and perceptions of the patriarchal culture about feminine and masculine roles. Gloria Anzaldua, Gayatri C. Spivak, Amy Tan, Alice Walker, Maya Angelou, Zora Neale Hurston, Sandra Cisneros and Toni Morrison are cited for their exemplary works which cut across national, cultural and racial boundaries and achieve recognition and freedom for themselves and for other women around the world to draw inspiration from their rebellious examples in the first place and to show how writing can become a source of empowerment for women.

\subsection{Potentials for Victims of Gender}

Like white women, American women of color rebel against the disempowering ideologies and stereotypes which the cultural, religious and educational institutions of patriarchal societies instill in women for the purpose of perpetuating gender hierarchies, ensuring their silence and compliance, and reproducing structures of oppression and exploitation. They simultaneously protest against the ethnocentric views of western feminists who represent Third World women as a monolithic other in order to obscure racial and ethnic differences and essentialize the hegemonic western culture. In addition, western feminists tend to belittle or ignore the important participation of women activists of color in the campaigns Rosa Parks, Ella Baker and Angela Davis led against the segregation system and the disenfranchisement of minorities during the civil rights movement in the 1960s.

In response to the ethnocentrism of western feminism, women in American ethnic minority groups propose a more ethnically and racially diverse concept of feminism. Barbara Smith (1980) perceives feminism as "the political theory and practice to free all women: women of color, working-class women, poor women, physically challenged women, lesbians, old women, as well as white economically privileged heterosexual women. Anything less than this is not feminism, but merely female self-aggrandizement." (49) The recognition of difference Smith engenders in this definition signifies two things. First, Third World feminism is a culturally and ethnically heterogeneous movement that seeks to achieve gender, racial and social equality, and to dismantle ageism and the cultural constructions of the homosexual/heterosexual binary oppositions. Second, women of color ought to forge transnational and interethnic coalitions to assert their interdependence and the diversity of their cultures and identities.

Women in American ethnic minority groups consequently ally themselves with their sisters in the Third World. Chandra Mohanty (1991) describes their transnational alliance as "viable" on the ground of their "common context of struggle rather than color or racial identifications." (7)

The characters of the narrator in Viramontes' novel and Maxine in Kingston's novel struggle against gender roles. Both the narrator and Maxine are young girls of immigrant parents trying to reproduce their cultural experiences in the USA. In the Moths, Viramontes contrasts the protagonist narrator with her older sisters, Teresa and Maisela, in terms of character and respect to feminine chores:

I wasn't even pretty or nice like my older sisters and I just couldn't do the girl things they could do. My hands were too big to handle the fineries of crocheting or embroidery and I always pricked my fingers or knotted my colored threads time and time again while my sisters laughed and called me bull hands (27).

Here, the narrator recognizes that Teresa and Marisela are not only more beautiful but also more talented in girlish things than her. Their talents meet the demands of the patriarchal society, which gives more credit to talented girls in the contest of finding a marriage partner. The narrator's "bull hands", however, signifies her masculinity and marks her rebellion against gender division and segregation of labor. That she can drive her grandmother's truck and plant wild lilies and jasmine suggests that she can learn embroidery too; yet, she ostensibly messes things up to convince her authoritative father that she cannot do such a feminine chore. The narrator's abstention from church, which she considers an accomplice with women's oppression, puts her in the same basket with her grandmother, Abuelita, who had been ostracized just for being a secular woman. Only after the death of Abuelita at the end of the story does the narrator see "the scars on her back, which were as thin as the life lines on the palms of her hands" (31). The scars on Abuelita's back document her suffering and portray her body as the shield with which she resisted patriarchy and realized her autonomy. They also empower the narrator to rebel and desegregate gender roles by performing such masculine chores as gardening and driving. In fact, the wild lilies and jasmine Abuelita used to plant symbolically stands for the revolutionary thoughts she has instilled in the mind of her granddaughter and the figurative rebirth she has undergone. In this sense, the narrator says:

Dying is lonely and I wanted to go to where the moths were, stay with her and plant chayotes whose vines would crawl up her fingers and into the clouds; I wanted to rest my head on her chest with her stroking my hair, telling me about the moths that lay within the soul and slowly eat the spirit up; I wanted to return to the waters of he womb with her so that we would never be alone again (32). 
Likening the body of Abuelita to a seed of chayotes that keeps growing until it crawls into the clouds perceives death as a window of freedom from patriarchal restrictions.

Similarly, young Maxine in The Woman Warrior resents the typical feminine roles women play and rejects to do woman's chores such as cooking and dishwashing. She confesses that "even now, unless I am happy, I burn the food when I cook. I don't feed people. I let the dirty dishes rot" (47-48). In "Fa Mu Lan", Maxine rejects the image of "good mother" which defines woman in relation to her husband and children and emphasizes the empowering potentials of writing and education which she metaphorically compares to Fa Mu Lan's sword. By relating the story of "No Name Woman", Maxine challenges the authority of her father and patriarchal mother, Brave Orchid, who warns her not to tell it to anybody. Maxine's decision to redefine her aunt as a victim rather than a sinner poses another challenge to patriarchy and displays her rejection of the miserable and tyrannical conditions under which her aunt lived and by which she was forced to get pregnant and commit suicide.

\subsection{Potentials for Victims of Ethnocentrism}

Considering its critique of the ethnocentric discourse of western feminism, its deconstruction of the orientalist representation of the orient, its frequent use of such postcolonial jargons as "otherness", "the subaltern", "hybridity" and "two-ness", and its documentation of the undeniable contributions of Igbo, Indian, Algerian, and Palestinian women to anti-colonial national movements, American multiethnic women writing can be very empowering and inspiring for the victims of the ethnocentric discourses of colonialism and nationalism. Racial communities designate certain ethnicities, languages and cultures as inferior, less developed and uncivilized in order to exploit and dominate them culturally, economically and politically. Toni Morrison in Beloved prescribes language and solidarity as means of liberation and empowerment to counteract racial practices in the American society. The fictional character of Baby Suggs, for instance, uses language to challenge the representations of black people as subhuman or white man's properties. In her self-love sermon to the black community of Cincinnati in the Clearing, Suggs asks them to love their mouths which the whites despise and try to mute. She also stresses the pivotal role solidarity can play in shielding black community against white man's raids, oppression and exploitation. This echoes the community's failure to alert Sethe about the approaching of the schoolteacher and its recent success in collectively exorcising Beloved and releasing Sethe from the past.

In common with Frantz Fanon, Edward Said and other anti-colonial intellectuals, women of color renounce nationalism for assuming a bourgeois and patriarchal character and reproducing social inequalities that characterized the colonial period. Gayatri Spivak (1987), for instance, rejects the dominant beliefs that the west is more civilized than the east or that the postcolonial nation state is more progressive and modern than it is in the precolonial era. She views nationalism as an instrument for suppressing marginalized groups and replacing colonialism with neocolonialism in postcolonial states. These anti-nationalist and anti-colonial attitudes by Spivak are recapitulated in her argument that

If nationalism is the only discourse credited with emancipatory possibilities in the imperialist theatre, then one must ignore the innumerable examples of resistance throughout the imperialist and pre-imperialist centuries, often suppressed by those very forces of nationalism which would be instrumental in changing the geopolitical conjuncture from territorial imperialism to neo-colonialism. (Spivak 1987: 245)

In her survey of the colonial and postcolonial histories of India, Spivak accuses nationalists of hypocrisy and partiality. She recounts how Mohandas K. Gandhi, leader of the Indian independence, used an egalitarian discourse of nationalism to mobilize the subaltern groups of women, peasants and laborers for participating in the passive protest campaigns known as civil disobedience movements. Indian nationalism, Spivak emphasizes, failed to realize emancipation and equality for the subaltern; rather, it further subordinated them by preserving existing hierarchies and power structures and concentrating all power and wealth in the hands of a few, namely the government and bourgeois elitism.

In Louis Erdrich's Love Medicine, the fictional characters Marie and Lulu rebel against the colonial culture which has displaced American Indian matriarchy and egalitarian culture, and deemed their native culture primitive and savage. Marie Kashpaw's conflict with Sister Leopolda over the sainthood of Sacred Heart Convent reveals a repressed desire to recover the American Indian matriarchy. Traditionally, American Indian mothers were in charge of administering domestic affairs, promoting social equality, maintaining peace and harmony with other tribes, and mediating between the tribe and outsiders. However, their prominence declines with the advent of white invaders who impose patriarchy and Christianity on American Indian tribes through physical and cultural genocide. Although Marie defeats Leopolda and becomes the saint, she resigns sainthood in favor of motherhood which, according to Paula Gunn Allen, "bring(s) vital beings into the world" (27) and "implied the highest degree of status in ritual cultures" (28).

However, Lulu devises a Four-pronged strategy to decolonize American Indians. First, she defies patriarchal tribalism which the whites institutionalize to demote American Indian women. Lulu's motherhood to eight children from different fathers not only thwarts the supremacy of tribal chiefs who intend to force her out of her house to build a souvenir factory, but also asserts her central role as a mother. Second, she represents Indians as dispossessed natives and whites as settlers or plunderers. In this sense, she says: "If we're going to measure land, let's measure right. Every foot and inch you're standing on, even if it's on the top of the highest skyscraper belongs to the Indians" (221). Third, she rebukes tribal chiefs for their complicity with the whites to whom they sold their lands for the "crumbs" (223) thrown to them on the floor to lick. Forth, she regresses to old ways and represents her people and gender as "natural artists" (304). This explains why she entrusts a medicine man to cure her son, Henry Junior, rather than takes him to a 
hospital, where "they just give them drugs" (149). In her perspective, Indian medication is better than the white's because the former treats both body and soul, whereas the latter treats the body only.

\subsection{Potentials for Victims of Class}

Socially, American multiethnic women writing promotes the deconstruction of class hierarchies and creation of a more egalitarian social system through its relation of autobiographical narratives featuring the social status and class struggle of native American women, black women and early women immigrants from Asia and Latin America. It signifies race and gender as factors for discrimination against women of color in terms of jobs and wages. The fall of the American family from a producer to a consumer under the new order of the industrial economy which concentrated power in the hands of those who produce priced commodities equally aroused white women and women of color to turn from housekeepers into industrial workers in challenge to the new economy and to meet the increasing demand for laborers during the First World War. Despite their invaluable contributions to the flourish of the US industry, women of color filled dirtier jobs and received lower wages than what both white men and women had owing to their gender and race. This awakened women of color to their marginal position in the society and stirred them to revolt against racism and classism.

Claudia Jones (1995) discusses the militant participation of Negro women in the struggle of the Negro liberation movement for civil rights and social justice and credits their militancy for the emergence of a parallel anti-fascist, antiimperialist and anti-capitalist coalition in which they actively participated. Their effective involvement in such a crossinterest coalition accounts for their neglect of the special concerns and needs of Negro women who had to serve as providers, guardians and protectors of their families against hunger, lynch terror and segregation under the shadow of Jim Crow laws. It is not surprising, Jones believes, that the "bourgeoisie is fearful of the militancy of the Negro woman, and for good reason. The capitalists know, far better than many progressives seem to know, that once Negro women undertake action, the militancy of the whole Negro people, and thus of the anti-imperialist coalition, is greatly enhanced." (108) What primarily scares the bourgeoisie is this collective sense of identification and interdependence which gives rise to cross-gender and transnational alliances between women of color and laborers around the world.

Ana Castillo in So Far From God protests against the proletarianization of women in multinational factories and the colonization of Third World countries. The fictional character Sofi runs for the mayor of Tom just to make some social changes. She, for instance, initiates cooperatives to decrease unemployment and poverty rates among women, help them pursue their college education, and release them from the exploitation of textile factories. In addition, she takes part in the Cross Procession which demands improving work conditions; and she protests against dumping radioactive waste in the sewer. Eventually, she establishes and runs M.O.M.A.S (Mother of Martyrs and Saints) society which attacks the US imperial war on Iraq and raises funds to help the martyrs' families there.

\section{Innovative Strategies of Empowerment}

American multiethnic women writing has created an ideologically, culturally and literarily diverse discourse to effectively empower women of color in their struggle against their multiple oppressors. The strategies of empowerment they developed include:

\subsection{Hybridization of Cultural Differences}

Women writers of color tend to embrace a hybrid identity to subvert the hegemony of their elite, colonial and patriarchal masters who seek to turn them into reproducers of their essentialist ideologies. Chela Sandoval (2003) highlights the tendency of women of color to cross boundaries in her emphasis that

This in-between-state, this third gender category, is also explored in writings of such wellknown authors as Maxine Hong-Kingston, Gloria Anzaldúa, Audre Lorde, Alice Walker and Cherrie Moraga, all of whom argue that U.S. third world feminists represent a different kind of human - new 'mestizas', 'Woman Warriors' who live and are gendered "between and among" the lines, 'Sister Outsiders' who inhabit a new psychic terrain which Anzaldúa calls 'the Borderland,' 'la nueva frontera'. (80)

The titles of the books she quotes such as Borderlands, Woman Warrior, Between Worlds and The Third Woman introduce a new perspective of identity and difference.

Audre Lorde (1984) discards the master's binary perception of difference as a threat and stresses the fluidity of identity and necessity of difference. Thus, she presumes that

Difference must be not merely tolerated, but seen as a fund of necessary polarities between which our creativity can spark like a dialectic. Only then does the necessity for interdependency become unthreatening. Only within that interdependency of different strengths, acknowledged and equal, can the power to seek new ways of being in the world generate, as well as the courage and sustenance to act where there are no charters. Within the interdependence of mutual (nondominant) differences lies that security which enables us to descend into the chaos of knowledge and return with true visions of our future, along with the concomitant power to effect those changes which can bring that future into being. Difference is that raw and powerful connection from which our personal power is forged. (LMT: 99). 
Lorde here favors ambivalence over coherence and tolerance as it incites inter-gender and interracial dialogue that fosters interdependence and mutual recognition and respect. After people of different gender, social and cultural identities acknowledge the virtues of plurality, Lorde believes they will immediately develop a desire to better know and value each other. Although this knowledge will lead neither to the integration of ambivalence nor to the deconstruction of binary oppositions, it will internally evoke each to correct the negative images about the other and to realize their interconnectedness. The notions of self-reflexivity and self-knowledge Lorde advances in her article equally free women and people of color from intellectual dependence on the masters and help them critically explore the self and the other and accordingly rethink the various ideologies that have determined their perception of difference for a very long time. There is no wonder then that Lorde mocks women writers who still believe in the illusion that the tools the masters equip them with such as male-oriented education and writing will lead to their empowerment. On the contrary, she stresses that the master's tools "may allow us temporarily to beat him at his own game, but they will never enable us to bring about genuine change" (99). This implies that feminisms can more or less function as disguised tools the masters can use to perpetuate their hegemonies unless women entirely unlearn the internalized knowledge they acquired from their masters and manage to fundamentally change the social, ideological and cultural structures by which roles, relationships and identities are redefined. The new intellectual and social atmosphere contributes to creating a more diverse community where ghettos and homophobia dissolve, plurality and a borderland identity prevail.

In comparison, Gloria Anzaldua in "La Prieta" embraces a hybrid identity that transcends cultural, racial and gender borders. She likens herself to

Shiva, a many-armed and legged body with one foot on brown soil, one on white, one in straight society, one in the gay world, the man's world, the women's one, one limb in the literary world, another in the working class, the socialist, and the occult worlds. A sort of spider woman hanging by one thin strand of web. Who, me confused? Ambivalent? Not so. Only your labels split me (205).

The image of the many-armed and legged spider woman Anzaldua metaphorically describes in the above quotation expresses her equal identification with the white and black, heterosexuals and homosexuals, men and women, artists and laborers; and it casts light on the multiple selves constituting her mestiza identity as a Mexican American woman living on the boundaries of different cultures. She, consequently, rejects the labels used to categorize the different aspects underlying her personality and turns the pressures for assimilation or exclusion into opportunities to synthesize a plural identity that includes all the contradictions defining her.

Anzaldua's inclusive notion of mestiza identity delineates the hybridized difference as a source of empowerment for the individual and the community in two ways. On one hand, it has individuals re-explore their visions of self and other from a pluralistic perspective. The attainability of an idiosyncratic vision of the world depends on whether people are willing to break with ethnocentric traditions, question myths about self and other, rewrite the history of ethnic encounters and reconstruct their ethnic identities. Anzaldua in Borderlands reflects on this in her emphasis that only "by creating a new mythos - that is, a change in the way we perceive reality, the way we see ourselves and the way we behave - la mestiza creates a new consciousness" (80). Mental change, for Anzaldua, becomes a precondition for the substantial reformation of the society and the realization of equity, solidarity and inclusion of multiple races and ethnicities in a new mestiza culture, so she assumes that "nothing happens in the 'real' world unless it first happens in the images in our heads" (87). Implicative is a call for both white Americans and minority Americans to use education as an effective means to recognize the worth of the other and tolerate difference. When oppressors become self-aware of the historic injustices and grievances they have inflicted upon minority groups and women, they will seek to redress their crimes and prejudices and create a more just and diverse society. Although the oppressed groups are demanded to forgive but not forget their oppression, they should free themselves from the dualisms inherent in their cultures and start to perceive their oppressors more as allies than opposites. Otherwise, they will convert into oppressors and reproducers of oppression as it is suggested by Paulo Freire (1970) who contends that "the authentic solution of the oppressoroppressed contradiction does not lie in a mere reversal of position, in moving from one pole to the other. Nor does it lie in the replacement of the former oppressors with new ones who continue to subjugate the oppressed." (57)

On the other hand, syncretic difference functions as a bridge to narrow down gaps between men and women, black and white, poor and rich, reconcile self and other, and nurture interdependence. Anzaldua in Gloria Anzaldua Reader builds on this "reprochement between self and other" (145) to establish the bases for universal alliances that cross national and gendered boundaries. She considers the demonstrations of the American women of color in support for the rights of laborers, gays and white middle class women as a translation of that cross-gender and cross-ethnic reconciliation and consolidation.

\subsection{Innovation of Literary Content}

The conception of writing as a space not only for the exploration and reconciliation of difference but also for resistance is another strategy American multiethnic women literature prescribes for the oppressed races and genders. The Palestinian author Ghassan Kanafani (1966) described the literary production of Palestinian writers from 1948 to 1966 as resistance literature because their writings mainly represented Israel as an imperial power and Palestine as a colonized nation whose people either live in exile or under occupation. His perception of literature as a means of resistance suggests that literary works by authors in peripheral social and political positions are supposed to resist 
occupation, decolonize people's consciousness from colonial ideologies, and voice their suppressed anger and desires of freedom and independence. He presumes that "resistance springs from these linguistic initiatives, working together with the rigidity of the conditions of the situation." (11) This implies that the linguistic and historical settings writers dramatize render literature as a mirror subjectively reflecting the history, culture and language of the colonized people. Kanafani's rejection of objectivity in resistance literature reverses power relations because it subordinates the colonizer to the colonized whom it seeks to empower and give voice to. Yet, he points out that the efficiency of literature in resisting colonialism depends on whether authors indulge in resistance movements, use the language spoken by the people under occupation and depict the geographical, historical and cultural settings of the occupied territories.

Feminists of color encountered a similar situation in which they were demanded by patriarchal and colonial authorities to detach social and political life from writing and produce impersonal texts in which they objectively describe reality and celebrate the virtues of marriage, domestic work and community service. Their awareness that the detachment from the politics, culture and economy of the society they live in would turn them away from realism towards gothic and magic realism arouses them to produce a historicized and politicized genre by which they can freely resist intellectual conformity and decolonize their writing, gender and race. As an act of decolonization, language empowers women of color to "quest for self, for the center of the self, which we women of color have come to think of the "other" - the dark, the feminine. Didn't we start to write to reconcile this other within us?" (Anzaldua 1981: 169) The reconciled self American women writers of color realize replaces the dichotomous self cultivated by the hegemonic ideologies of patriarchy and white supremacy. While the model of the reconciled self breeds diversity, harmony and interdependence, the model of the dichotomous self widens gaps and deepens conflicts and inequities to divide and rule the heterogeneous other. In addition, language has the potentials to rewrite identities and histories and reform social structures. The exclusionary perception of history and culture in the writings of male and mainstream writers become inclusive in the writings of women of color who locate their power in cooperation and integration with others; thus, Anzaldua writes to "record what others erase when I speak, to rewrite the stories others have miswritten about me, about you. To become more intimate with you. To discover myself, to make myself, to achieve self-autonomy (169). On this basis, writing is viewed as a tool for preserving the histories of women of color and their ethnic communities from distortion and misinterpretation. It also gives voice to self and other and creates a platform for inter-gender, interracial and intercultural dialogue which results in the resolution of conflicts and restoration of peaceful coexistence and cooperation.

\subsection{Hybridization of Language and Genre}

This major innovation in the content of the literary works by women writers of color is accompanied with creativity in language and writing. Anzaldua, for instance, inventively uses Spanglish, a hybrid language combining Spanish and English, and blends prose, poetry and critical theories in her works to hybridize languages and genres, establish a pluralist literary canon in Chicana literature and undermine the dominant norms of the masters. Moreover, women writers of color tend to use the first person narrative mode to relate their stories of oppression and struggle from the perspective of an "I". This makes them visible and helps them express their subjectivity and idiosyncrasy.

\section{Conclusion}

Women writers of color produced an ideologically heterogeneous genre whose premises of the deconstruction of dualities, reconstruction of cultures and societies, and restoration of the rights and freedoms confiscated from the oppressed groups intersects with the resistance literature of feminism, communism and anti-colonialism. Their genre is culturally heterogeneous as well because American writers of color descend from countries as far as Asia, Africa, the Middle East and Latin America with which they still identify and maintain transnational ties. The geographical and historical settings of their works, therefore, go beyond the American context to their places of descent where men and women struggle against similar oppressive, exploitative and exclusionary practices. This accounts for the plurality and universality of American multiethnic women writing which brings women of color into inclusive coalitions with other oppressed groups. The proven empowering potentials and legacies of this genre as my research work suggests largely stem from its realistic representation of social and political life, appreciation of difference and innovative use of language.

\section{References}

Allen, P. G. (1992). The Sacred Hoop: Recovering the Feminine in American Indian Traditions. Beacon Press.

Anzaldua, G. (1981). La Prieta. In C. Moraga \& G. Anzaldua (Eds.), This Bridge Called My Back: Writings by Radical Women of Color (pp. 198 - 209). Massachusetts: Persephone Press.

Anzaldua, G. (1981). Speaking in Tongues: a Letter to Third World Women Writers. In C. Moraga \& G. Anzaldua (Eds), This Bridge Called My Back: Writings by Radical Women of Color (pp. 165 - 190). Massachusetts: Persephone Press.

Anzaldua, G. (1987). Borderlands/La Frontera: The New Mestiza. San Francisco: Aunt Lute.

Anzaldua, G. (2009). Gloria Anzaldua Reader. A. Keating (Ed.). Duke University Press.

Castillo, A. (2005). So Far From God. W.W. Norton \& Company.

Erdrich, L. (1993). Love Medicine. Harper Perennial. 
Jones, C. (1995). An End to the Neglect of the Problems of the Negro Woman! In B. Guy-Sheftall (Ed.), Words of Fire: An Anthology of African American Feminist Thought (108 - 123). New York: The New Press.

Kanafani, G. (1966). Literature of Resistance in Occupied Palestine 1948 -1966. Cyprus: Rimal Publications.

Kingston, H. M. (1989). The Woman Warrior: Memoirs of a Girlhood among Ghosts. Vintage.

Lorde, A. (1984). Sister Outsider. Essays and Speeches by Audre Lorde. California: The Crossing Press.

Mohanty, T. C. (1991). Third World Women and the Politics of Feminism. Indiana University Press.

Morrison, T. (2004). Beloved. Vintage.

Ogbuehi, C.U. (1999). Women, Literature and Empowerment. Nsukka Journal of the Humanities, 10, 42 - 54.

Paulo, F. (1970). The Pedagogy of the Oppressed. (M. B. Ramos, Trans.). New York: Continuum.

Sandoval, C. (2003). US Third World Feminism: The Theory and Method of Oppositional Consciousness in the Postmodern World. In R. Lewis \& S. Mills (Eds.), Feminist Postcolonial Theory: A Reader (pp. 75 - 102). Routledge.

Smith, B. (1980). Racism and Women's Studies. Frontiers: A Journal of Women Studies, 5(1), 48 -49.

Spivak, C. G. (1987). In Other Worlds: Essays in Cultural Politics. Routledge.

Viramontes, M. H. (1995). The Moths and Other Stories. Arte Publico Press. 